\title{
Stem Cells, Sex, and Procreation
}

\author{
JOHN HARRIS
}

Sex is not the answer to everything, though young men think it is, ${ }^{1}$ but it may be the answer to the intractable debate over the ethics of human embryonic stem cell research. In this paper, I advance one ethical principle that, as yet, has not received the attention its platitudinous character would seem to merit. ${ }^{2}$ If found acceptable, this principle would permit the beneficial use of any embryonic or fetal tissue that would, by default, be lost or destroyed. More important, I make two appeals to consistency, or to parity of reasoning, that I believe show that no one who either has used or intends to use sexual reproduction as their means of procreation, ${ }^{3}$ nor indeed anyone who has unprotected heterosexual intercourse, nor anyone who finds in vitro fertilization (IVF) acceptable, nor anyone who believes that abortion is ever permissible can consistently object on principle ${ }^{4}$ to human embryo research nor to the use of embryonic stem cells for research or therapy.

This paper has four parts. I begin by simply reviewing the range of ethical issues raised by human embryo stem cell (HESC) research or therapy. I then examine why human stem cells are so important. Third, I review the current state of social and regulatory policy on stem cells, and finally, I say some positive things about the ethics of HESC research and therapy.

\section{What Are the Ethical Issues?}

The ethical aspects of human stem cell research raise a wide variety of controversial and important issues. Many of these issues have to do with the different sources of stem cells. In principle, stem cells can be obtained from adults, from umbilical cord blood, from fetal tissue, and from embryonic tissue. Clearly, there are widely differing views as to the ethics of sourcing stem cells in these four different ways. For the moment, there is general consensus that embryos are the best source of stem cells for therapeutic purposes, but this may, of course, change as the science develops. Then there is the question of whether embryos or fetuses may be deliberately produced to be sources of stem

This paper draws on, but also answers objections to, my earlier paper "The ethical use of human embryonic stem cells in research and therapy" published in: Burley JC, Harris J, eds. A Companion to Genethics: Philosophy and the Genetic Revolution. Oxford: Blackwell; 2001. I am indebted to my colleague Louise Irving for the data on social policy in Europe and to Julian Savulescu for many stimulating conversations and exchanges. Work on this paper was supported by a project grant from the European Commission for EUROSTEM under its Quality of Life and Management of Living Resources Programme, 2002. 


\section{John Harris}

cells, whether they are also intended to survive stem cell harvesting and grow into healthy adults.

The European Group on Ethics, which advises the European Parliament, is one of the few to have highlighted the women's rights issues that arise here. In particular, we should bear in mind that women as the most proximate sources of embryonic and fetal material and hence also of cord blood may be under special pressures and indeed risks if these are to be the sources of stem cells.

There are issues of free and informed consent, both of donors and recipients; the responsibility of accurate risk-benefit assessment; and the fact that particular attention needs to be paid to appropriate ethical standards in the conduct of research on human subjects. There are issues concerning the anonymity of the donors and security and safety of cell banks and of the confidentiality and privacy of the genetic information as well as the tissue they contain. Finally, there are issues of commerce and remuneration for those taking part and of the transport and security of human tissue and genetic material and information across frontiers both within the European Union and worldwide. All of these issues are important, but most of them have received extensive discussion over the past few years. For this reason, I shall not look in detail at these issues.

Before considering the ethics of such use in detail, we need to understand the possible therapeutic and research uses of stem cells and, equally, the imperatives for research and therapy.

\section{Why Embryonic Stem Cells?}

Embryonic stem cells were first grown in culture as recently as February 1998 by James A. Thomson of the University of Wisconsin. In November of that year, Thomson announced in Science that such human embryo stem cells formed a wide variety of recognizable tissues when transplanted into mice. ${ }^{5}$ As Roger A. Pedersen noted recently:

Research on embryonic stem cells will ultimately lead to techniques for generating cells that can be employed in therapies, not just for heart attacks, but for many conditions in which tissue is damaged.

If it were possible to control the differentiation of human embryonic stem cells in culture the resulting cells could potentially help repair damage caused by congestive heart failure, Parkinson's disease, diabetes, and other afflictions. They could prove especially valuable for treating conditions affecting the heart and the islets of the pancreas, which retain few or no stem cells in an adult and so cannot renew themselves naturally. ${ }^{6}$

Stem cells then might eventually enable us not only to grow tailor-made human organs that, using cloning technology of the type that produced Dolly the sheep, could be made individually compatible with their designated recipients. In addition to tailor-made organs or parts of organs, such as heart valves, it may be possible to use human embryonic stem cells to colonize damaged parts of the body, including the brain, and to promote the repair and regrowth of damaged tissue. These possibilities have long been theoretically understood, but it is only now with the isolation of human embryonic stem cells that their benefits are being seriously considered. 
Now that we have noted some of the research and therapeutic possibilities, it is important to remind ourselves of the moral reasons we have to pursue stem cell research. "Research" always sounds like such an abstract and even vainglorious objective when set against passionate feelings of fear or distaste. We need to remind ourselves of the human benefits that stem from research and the human costs of not pursuing research.

\section{Stem Cells for Therapy}

It is difficult to estimate how many people might benefit from the products of stem cell research should it be permitted and prove fruitful. Most sources agree that the most proximate use of HESC therapy would be for Parkinson's disease. Parkinson's disease is a common neurological disease, the prevalence of which increases with age. The overall prevalence (per 100 population in persons 65 years of age and older) is 1.8. ${ }^{7}$ Parkinson's disease has a disastrous effect on the quality of life. Another source speculates that "the true prevalence of idiopathic Parkinson's disease in London may be around 200 per $100,000 .{ }^{\prime \prime}$ In the United Kingdom, around 120,000 individuals have Parkinson's disease, ${ }^{9}$ and it is estimated that Parkinson's disease affects between one and one-and-a-half million Americans. ${ }^{10}$ Untold human misery and suffering could be prevented if Parkinson's disease became treatable. If Roger Pedersen's hopes for stem cell therapy are realized and treatments become available for congestive heart failure, diabetes, and other afflictions and if, as many believe, tailor-made transplant organs will eventually be possible, then literally millions of people worldwide will be treated using stem cell therapy.

When a potential new therapy holds out promise of dramatic cures we should, of course, be cautious, if only to dampen false hopes of an early treatment. Equally, however, for the sake of all those awaiting therapy, we should pursue the research that might lead to therapy with all vigor. To fail to do so would be to deny people who might benefit from the possibility of therapy.

\section{Immortality}

Finally, I want to note the possibility of therapies that would extend life, perhaps even to the point at which humans might become in some sense "immortal." 11 This, albeit futuristic, dimension of stem cell research raises important issues that are worth serious consideration. Many scientists ${ }^{12}$ now believe that death is not inevitable, that the process whereby cells seem to be programmed to age and die is a contingent "accident" of human development that can in principle and perhaps in fact be reversed, and that part of that reversal may flow from the regenerative power of stem cells. ${ }^{13}$ I have discussed immortality at length elsewhere, ${ }^{14}$ but, before turning to the ethics of stem cell research and therapy, I wish to note one important possible consequence of life-extending procedures.

\section{Human Evolution and Species Protection}

HESC research in general and the immortalizing properties of such research in particular raise another acute question. If we become substantially longer lived 
and healthier, and certainly if we transformed ourselves from "mortals" into "immortals," we would have changed our fundamental nature. One of the common defining characteristics of a human being is our mortality. Indeed, in English we are "mortals," or persons; not "immortals" or gods, demigods, or devils. Is there then any moral reason to stay as we are simply because it is "as we are"? Is there something sacrosanct about the human life form? Do we have moral reasons against further evolution whether it is "natural" Darwinian evolution or evolution determined by conscious choice?

One choice that may confront us concerns whether to attempt treatments that might enhance human functioning, so-called enhancement therapies. For example, it may be that, because of their regenerative capacities, stem cells inserted into the brain to repair damage might in a normal brain have the effect of enhancing brain function. Again, it would be difficult if the therapies are proved safe in the case of brain-damaged patients to resist requests for their use as enhancement therapies. What after all could be unethical about improving brain function? We don't consider it unethical to choose schools on the basis of their (admittedly doubtful) claims to achieve this; why would a more efficient method seem problematic? ${ }^{15}$

Marx famously said, "The purpose of philosophy is not to understand the world but to change it." Perhaps the purpose of genetics, and indeed of life sciences more generally, is not to understand humanity but to change it. We should not, of course, attempt to change human nature for the worse, and we must be very sure that in making any modifications we would in fact be changing it for the better and that we can do so safely, without unwanted side effects. However, if we could change the genome of human beings, say by adding a new manufactured and synthetic gene sequence that would protect us from most major diseases and allow us to live on average $25 \%$ longer with a healthy life throughout our allotted time, I for one, would want to benefit from this and I have not been able to find an argument against so doing that is even worth citing for rebuttal. In the West, human beings now do live on average $25 \%$ longer than we did 100 years ago, but this is usually cited as an unmitigated advantage of "progress." It is not widely regretted, there is no wailing and gnashing of teeth; why would regrets or fears be appropriate if a further health gain could be obtained only by species modification or "directed" evolution? The point is sometimes made that, so long as humans continued to be able to procreate after any modifications, which changed our nature, we would still be, in the biological sense, members of the same species. But, the point is not whether we remain members of the same species in some narrow biological sense but whether we have changed our nature and perhaps with it our conception of normal species functioning.

\section{Stem Cell Research and Social Policy ${ }^{16}$}

\section{The United Kingdom's Welcome for Stem Cell Research}

On 22 January 2001, the United Kingdom became the first country, certainly in Europe, to approve HESC research, albeit with what the government described as "adequate safeguards." The United Kingdom government had set up an "expert group" under the Chief Medical Officer (CMO's Expert Group), and this group finally reported in June 2000. In August 2000, the government 
published its response broadly welcoming the report and accepting all of its major recommendations. ${ }^{17}$ These recommendations were the subject of a free vote in both houses of the U.K. Parliament, and this vote was overwhelmingly for approval of stem cell research and so-called therapeutic cloning. The CMO's Expert Group relied for such argument mainly on the consistency of such research with embryo research already permitted and well established in the United Kingdom under the Human Fertilization and Embryology Act 1990 and the regulation of research under that Act by the Human Fertilization and Embryology Authority. Basically, under that act, research on embryos is permitted to investigate problems of infertility and other limited purposes. Now the list of permitted purposes is extended to include HESC research.

The U.K. government's policy on stem cells suffered a reverse when a legal action brought by the Pro-Life Alliance succeeded, on 15 October 2001, in getting a declaration that cloning by cell nuclear substitution was outside the terms of the Human Fertilization and Embryology Act 1990. This was because that Act had foolishly and erroneously defined an embryo as "the product of fertilization," which of course embryos produced by "the Dolly method" are not, unless, because they use a cell nucleus produced by fertilization when the original organism was conceived, the relevant act of fertilization can be displaced a generation. However, the Pro-Life Alliance lost its case on appeal, and emergency legislation rushed through the U.K. Parliament has banned reproductive cloning, the government repeating the unsupported ${ }^{18}$ claim that human reproductive cloning was "ethically unacceptable." 19

Before addressing head-on the ethics of stem cells research as I see it, it is important to place stem cell research in a European and world perspective. There are few comprehensive legal or regulatory frameworks for stem cell research throughout the European Union. Many countries are without any legislation, and where laws are in place, they range from an absolute prohibition on embryo research ${ }^{20}$ to the permissibility of the creation of embryos for research purposes. ${ }^{21}$ This diversity of opinion is a reflection of existing cultural and religious differences. The strength of feeling in some countries regarding embryo research makes even compromise positions difficult to achieve. Governments have to balance strongly held beliefs regarding the moral status of the embryo and fears of instrumentalization against the promise of remarkable advances in the treatment of disease. There are conflicting duties between state responsibility for the health of their populations and the protection of their moral sensibilities.

\section{The Position of European Union Countries}

In most E.U. countries, there is a parallel between the permissibility of embryo research and the permissibility of abortion. Ireland is the only E.U. country whose constitution affirms the right to life of the unborn, where this right is equal to that of the mother, 22 although it is unclear whether this constitutional right applies from fertilization or implantation. Despite the constitutional wording, abortion is legitimate if the life of the mother is in immediate danger. Rape, incest, or fetal abnormalities are no justification, however. There is a tension between this attitude and the European Court of Justice decision that abortion constitutes a medical service within the meaning of the European Treaties and that any limitation on the provision of such services by a Member 
State was a matter for the European Union rather than Irish law. ${ }^{23}$ Ireland had to negotiate special provisions in the Maastricht treaty to maintain its antiabortion measures. Many applicant countries with bans or restrictions on abortions, such as Poland, Slovakia, Lithuania, Hungary, Slovenia, the Czech Republic, and Malta, may have to do the same.

Belgium and the Netherlands conduct embryo research without a framework of legislation. Portugal, where abortion is illegal except in cases of rape or serious medical reasons, and banned regardless after the twelfth week, has no legislation but no research. It is banned in Austria, Germany, and even France, but the latter allows "the study of embryos without prejudicing their integrity" 24 and preimplantation diagnosis. The Spanish constitution offers protection only to the in vitro viable embryo; the criteria for viability leave out spare embryos. ${ }^{25}$ Embryo research is permissible under specified conditions in Finland, Spain, and Sweden. The most liberal research conditions are to be found in the United Kingdom, where even the creation of embryos for research purposes has been legal since the 1990 Human Fertilisation and Embryology Act came into force. The legal situation in nine European countries is either under review or being revised or amended. For those countries, and the ones with no legislation at all, the situation may be guided by international regulations.

\section{The United States' Position}

The United States seems to share some of Germany's hypocrisy and indecision on this issue. Ten states have passed laws regulating or restricting research on human embryos, fetuses, or unborn children, and at the federal level funding is prohibited to support any research in which embryos are destroyed. As I discuss later, however, this federal prohibition is ominously restrictive and would seem to condemn a number of other practices as well. ${ }^{26}$

\section{International Guidelines}

International guidelines provide little clarity specifically on human embryo research. Apart from the wide international agreement on the prohibition of human reproductive cloning, agreements at the European level have left the permissibility of particular research to the discretion of each member state. There are few guidelines, but if research is authorized by a member state, then respect for human dignity requires an appropriate regulatory framework and the provision of guarantees "against risks of arbitrary experimentation and the instrumentalisation of embryos." 27 Both Italy and Greece rely on the Council of Europe's Convention of Human Rights and Biomedicine, Article 18, which stipulates only two conditions: a prohibition on producing embryos for research purposes and the adoption of rules designed to ensure adequate protection of embryos. ${ }^{28}$ To date, only three countries have ratified this convention. An added protocol prohibiting human cloning took effect in 2002. Human cloning was also banned by the Charter of Fundamental Rights of the European Union in December 2000, as are eugenic practices but, surprisingly for such a recent statement, it does not comment explicitly on embryo research. ${ }^{29}$ The European Parliament has stated its opposition both to therapeutic cloning and to the creation of spare embryos. Subsequently, the European Group of Ethics in Science and New Technologies to the European Commission, while advocating 
the allocation of a community budget to research on spare embryos from IVF treatment, confirmed the position that it considered the creation of embryos from donated gametes for research purposes ethically unacceptable and deemed therapeutic cloning as premature. ${ }^{30}$ Those countries that have commissioned an exploration of the issues from their National Ethics Committees or similar bodies provide an insight into the problems of achieving consistency of legislation.

\section{Consistency of Legislation}

There are many problems regarding the consistency of legislation throughout the E.U. countries. There often exist a constitutional right to freedom of research and a responsibility to ensure the health of their citizens. Again, Germany is an interesting illustration of the paradoxes that stem cell research has generated in Europe. Abortion is technically illegal in Germany, but women are not penalized, provided they receive counseling at a state-approved center, which may then issue them a certificate. ${ }^{31}$ So, there is a situation where abortion is permissible for a variety of reasons, where the abortion pill RU-486 is available, ${ }^{32}$ but where research on embryos is prohibited.

Germany also provides a constitutional right to freedom of research at the individual and institutional levels and a constitutional duty for the state to protect the life and health of its citizens. ${ }^{33}$ This was a consideration for many states who debated the ethics of this research. Germany, like the United States, opted for a compromise position when the Federal Parliament voted to permit limited import of embryonic stem cell lines created before 30 January 2002 while maintaining a ban on their derivation within German laboratories. ${ }^{34}$ For France, where embryo research is also prohibited, the ethics committee struggled with the fact that prohibition had halted HESC research when the therapeutic possibilities make it very desirable. The law is currently under review there, and supporters of HESC research pointed out that a "duty of solidarity" with individual suffering prohibits any attempt to stop research. ${ }^{35}$ There were pragmatic considerations in the acknowledgment that this research will continue elsewhere and if it produces the results it promises it was considered that French researchers would have no choice but to pursue it anyway. ${ }^{36}$ The dilemma now is whether to legislate directly and have safeguards that reflect the sensibilities of French society. The French also raise the concern that improved technical skills in IVF will lead to a decrease in the number of spare embryos. Their ethics committee recommends that the question of oocyte extraction and culture will need to be dealt with explicitly by law to prevent any risk of creating a market situation that would put psychological pressure on women. ${ }^{37}$

\section{Benefiting from Evil?}

Nations whose constitution (or, for that matter, democratic will) provides for freedom of research and imposes an obligation on the state to protect the lives and health of citizens and that have outlawed HESC research may face an agonizing dilemma should this research produce a therapeutic success. They will have to decide whether to make the resulting therapy available to their citizens, thereby risking the charge of exploiting and benefiting from the 


\section{John Harris}

wickedness of others, or face the unhappy prospect of watching their citizens die while those of other countries receive treatment. Of course, in reality, this will not quite be the dilemma because many citizens will seek treatment abroad, but the poor, as ever, are most likely to suffer from such a policy. ${ }^{38}$

The Italian National Bioethics Committee was split on the permissibility of creating embryos for research, a split grounded in the status of the embryo. Some members thought even the use of cryogenically frozen embryos, of which there is a considerable surplus, was not ethically justifiable, as respect for human beings prevents instrumental use of these embryos. ${ }^{39}$ Those who were in favor of research mentioned the additional consideration of the autonomy of women and couples in deciding to donate their eggs and decide on the fate of their nonimplanted embryos. ${ }^{40}$ Despite the legal and constitutional issues and the concerns of pragmatism and consistency, the status of the embryo is a continuous sticking point in the attempt to guide social policy. The religious positions all comment on the point that they believe life begins, and this gives an insight into the debate.

\section{The Ethics of Stem Cell Research}

Stem cell research is of ethical significance for three major reasons:

1. It will for the foreseeable future involve the use and sacrifice of human embryos.

2. Because of the regenerative properties of stem cells, stem cell therapy may always be more than therapeutic-it may involve the enhancement of human functioning and indeed the extension of the human lifespan.

3. So-called therapeutic cloning - the use of cell nuclear replacement to make the stem cells clones of the genome of their intended recipient-involves the creation of cloned pluripotent and possibly totipotent cells, which some people find objectionable.

Elsewhere I have discussed in detail the ethics of genetic enhancement ${ }^{41}$ and the ethics of cloning, ${ }^{42}$ and I noted above the immortalizing potential of stem cell research. In this essay, I concentrate on objections to the use of embryos and fetuses as sources of stem cells.

Given that, currently, the most promising source of stem cells for research and therapeutic purposes is either aborted fetuses or preimplantation embryos, their recovery and use for current practical purposes seems to turn crucially on the moral status of the embryo and the fetus. A number of recent indications are showing promise for the recovery and use of adult stem cells. It was reported recently that Catherine Verfaillie and her group at the University of Minnesota had successfully isolated adult stem cells from bone marrow and that these seemed to have pluripotent properties (i.e., capable of development in many ways but not in all, and not capable of becoming a new separate creature) like most HES cells. ${ }^{43}$ Simultaneously, Nature Online published a paper from Ron McKay at NIH showing the promise of embryo derived cells in the treatment of Parkinson's disease. ${ }^{44}$

This indicates the importance of pursuing both lines of research in parallel. The dangers of abjuring embryo research in the hope that adult stem cells will 
be found to do the job adequately is highly dangerous and problematic for a number of reasons. The first is that we do not yet know whether adult cells will prove as good as embryonic cells for therapeutic purposes. At the moment there is simply much more accumulated data and much more therapeutic promise from human embryonic stem cells. The second is that it might turn out that adult cells will be good for some therapeutic purposes and human embryonic stem cells for others. Third, we already know that it is possible to modify or replace virtually any gene in human embryonic stem cells; whether this will also be true of adult stem cells has yet to be established. Finally, it would be an irresponsible gamble with human lives to back one source of cells rather than another and to make people wait and possibly die while what is still the less favored source of stem cells is further developed. This means that the ethics of HESC research is still a vital and pressing problem and cannot for the foreseeable future be bypassed by concentration on adult stem cells.

\section{Stem Cells from Early Embryos}

It is possible to remove cells from early preimplantation embryos without damage to the original embryo. This may be one solution to the problem of obtaining embryonic stem cells. However, if the cells removed are totipotent (i.e., capable of becoming literally any part of the creature, including the whole creature), and if moreover they are capable of deciding until the cell mass achieves sufficient cells for autonomy (i.e., the ability to implant successfully and continue to grow to maturity) ${ }^{45}$ then they are in effect separate zygotes, they are themselves "embryos," and so they must be protected to whatever extent embryos are protected. If however, such cells are merely pluripotent, then they could not be regarded as embryos and the use of them would, presumably, not offend those who regard the embryo as sacrosanct. Unfortunately, it is not at present possible to tell in advance whether a particular cell is totipotent or simply pluripotent. This can only be discovered for sure retrospectively by observing the cells capabilities.

I will now set out one ethical principle that I believe must be added to the central principles cited in guiding our approach to HESC research and raise two issues of the consistency of attitudes and judgments about stem cell research with other practices and treatments used and considered acceptable (albeit with qualifications) not only in the European Union but indeed in the world at large. The two issues of consistency are:

1. consistency of stem cell research with what is regarded as acceptable and ethical with respect to normal sexual reproduction

2. consistency with attitudes to and moral beliefs about abortion and assisted reproduction.

The ethical principle that I believe we all share and that applies to the use of embryos in stem cell research is the Principle of Waste Avoidance.

\section{The Principle of Waste Avoidance}

This widely shared principle assumes that it is right to benefit people, if we can, and wrong to harm them, and it states that, faced with the opportunity to 
use resources for a beneficial purpose when the alternative is that those resources are wasted, we have powerful moral reasons to avoid waste and do good instead. I will start with consideration of the first requirement of consistency.

Lessons from sexual reproduction. Let us start with the free and completely unfettered liberty to establish a pregnancy by sexual reproduction without any "medical" assistance. What are people and societies who accept this free and unfettered liberty committing themselves to? What has a God who has ordained natural procreation committed herself to?

We now know that for every successful pregnancy that results in a live birth many, perhaps as many as five, ${ }^{46}$ early embryos will be lost or will "miscarry" (although these are not perhaps "miscarriages" as the term is normally used because this sort of very early embryo loss is almost always entirely unnoticed). Many of these embryos will be lost because of genetic abnormalities, but some would have been viable. Many people believe that the fact that perhaps a large proportion of these embryos are not viable somehow makes their sacrifice irrelevant. But those who believe that the embryo is morally important do not usually believe that this importance applies only to healthy embryos. Those who accept the moral importance of the embryo would be no more justified in discounting the lives of unhealthy embryos than those who accept the moral importance of adult humans would be in discounting the lives of the sick or of persons with disability.

How are we to think of the decision to attempt to have a child in the light of these facts? One obvious and inescapable conclusion is that God and/or nature has ordained that "spare" embryos be produced for almost every pregnancy and that most of these will have to die in order that a sibling embryo can come to birth. Thus, the sacrifice of embryos seems to be an inescapable and inevitable part of the process of procreation. It may not be intentional sacrifice, and it may not attend every pregnancy, but the loss of many embryos is the inevitable consequence of the vast majority (perhaps all) pregnancies. For everyone who knows the facts, it is a conscious, knowing, and therefore deliberate sacrifice; and for everyone, regardless of "guilty" knowledge, it is part of the true description of what they do in having or attempting to have children.

We may conclude that the production of spare embryos, some of which will be sacrificed, is not unique to assisted reproduction technologies (ART); it is an inevitable (and presumably acceptable, or at least tolerable?) part of all reproduction.

Both natural procreation and ART involve a process in which embryos, additional to those that will actually become children, are created only to die. I will continue to call these "spare" embryos in each case. If either of these processes is justified it is because the objective of producing a live healthy child is judged worth this particular cost. The intentions of the actors, appealed to in the frequently deployed but fallacious doctrine of double effect, ${ }^{47}$ are not relevant here. What matters is what the agents knowingly and voluntarily bring about. That this is true can be seen by considering the following example.

Suppose we discovered that the use of mobile telephones within 50 meters of a pregnant woman resulted in a high probability, near certainty, of early miscarriage. No one would suggest that, once this is known, it would be legitimate to continue use of mobile telephones in such circumstances on the 
grounds that phone owners did not intend to cause miscarriages. Any claim by phone users that they were merely intent on causing a public nuisance or, less probably, making telephonic communication with another person and therefore not responsible for the miscarriages would be rightly dismissed. It might, of course, be the case that we would decide that mobile communications were so important that the price of early miscarriage and the consequent sacrifice of embryos was a price well worth paying for the freedom to use mobile telephones. And this is, presumably, what we feel about the importance of establishing pregnancies and having children. Mobile telephone users, of course, usually have an alternative method of communication available, but let us suppose they do not.

This example shows the incoherence of the so-called doctrine of double effect. The motives or primary purposes of the phone user are clearly irrelevant to the issue of their responsibility for the consequences of their actions. They are responsible for what they knowingly bring about. The only remaining question is whether, given the moral importance of what they are trying to achieve (phoning their friends), the consequent miscarriages are a price it is morally justifiable to exact to achieve that end. Here the answer is clearly "no." Sometimes proponents of the doctrine of double effect attempt to make proportionality central to the argument. It is not, so it is claimed, the fact that causing miscarriage is not the primary or first intention or effect that matters but the fact that miscarriage is a serious wrong compared with the benefit of using a mobile telephone. However, this is to miss the point of the doctrine of double effect. Proportionality cannot be the issue because the doctrine of double effect was designed to exculpate people from the wrong of intending a forbidden act. The proportionality of the various outcomes cannot speak to the issue of primary or second effects. Only the true account of what the agents wanted to achieve or were "trying to do," of what the main intention or purpose actually was or is, can do that.

However, when we pose the same question about the moral acceptability of sacrificing embryos in pursuance of establishing a successful pregnancy, the answer seems different. My point is that the same issues arise when considering the use of embryos to obtain embryonic stem cells. Given the possible therapeutic uses I have reviewed, it would be difficult, I suggest, to regard such uses as other than morally highly significant. Given that decisions to attempt to have children using sexual reproduction as the method (or even decisions to have unprotected intercourse) inevitably create embryos that must die, those who believe having children or even running the risk of conception is legitimate cannot consistently object to the creation of embryos for comparably important moral reasons. The only remaining question is whether the use of human embryonic stem cells for therapies designed to save lives and ameliorate suffering are purposes of moral importance comparable to those of attempting to have (or risking the conception of) children by sexual reproduction.

The conscious voluntary production of embryos for research, not as the by-product of attempts (assisted or not) at reproduction, is a marginally different case, although some will think the differences important. However, if the analysis so far is correct, then this case is analogous in that it involves the production and destruction of embryos for an important moral purpose. All that remains is to decide what sorts of moral objectives are comparable in importance to that of producing a child. Although some would defend such a 


\section{John Harris}

position, ${ }^{48}$ it would seem more than a little perverse to imagine that saving an existing life could rank lower in moral importance to creating a new life. Assisted reproduction is, for example, given relatively low priority in the provision of healthcare services. Equally, saving a life that will exist in the future seems morally comparable to creating a future life. In either case, the moral quality and importance of the actions and decisions involved and of their consequences seem comparable.

Instrumentalization. It is important to note that prolife advocates or Catholics are necessarily acting instrumentally when they attempt to procreate. They are treating the 1-4 embryos that must be sacrificed in natural reproduction as a conscious (though not intended) means to have a live birth. This is something Catholics certainly and probably most others who hold a "prolife" position should not do.

However, the issue is not whether Catholics or those who take a prolife position may or may not be permitted to create embryos, which certainly or highly probably will die prematurely, and whether this constitutes reckless endangerment of embryos or even the unjustifiable killing of embryos. Rather, the facts of life, the facts of natural reproduction, show that the creation and destruction of embryos is something that all those who indulge in unprotected intercourse and certainly all those who have children are engaged in. It is not something that only those who use assisted reproduction or those who accept experimentation on embryos are "guilty" of. It is a practice in which we are all, if not willing, at least consenting participants, and it shows that a certain reverence for or preciousness about embryos is misplaced.

Embryo-sparing ART. It might be said that there is a difference-those who engage in assisted reproduction engage in the destruction of embryos at a greater rate than need be. Those who engage in sex are not engaged in the destruction of embryos at a greater rate than is required for the outcome they seek. It would be interesting to know whether, if a creating a single embryo by IVF became a reliable technique, prolife supporters would feel obliged to use this method rather than sexual reproduction because of its embryo-sparing advantages. It looks as though there would indeed be a strong moral obligation to abandon natural procreation and use only embryo-sparing ART.

Consider a fictional IVF scenario. A woman has two fertilized eggs and is told it is certain that if she implants both only one will survive but that if she implants only one it will not survive. Would she be wrong to implant two embryos to ensure a successful singleton pregnancy? This example is, of course, fictional only in terms of the degree of certainty supposed. It is good practice in IVF to implant two or three embryos in the hope of achieving the successful birth of one child. Thus, in normal IVF as in normal sexual reproduction, the creation and "sacrifice" of embryos in pursuit of a live child is not only accepted as necessary but is part of the chosen means for achieving the objective. Most people would, I believe, judge this to be permissible, and indeed it is what often happens in successful IVF pregnancies, where up to three embryos are implanted in the hope of one live birth. Even in Germany, where stem cell research using embryos is currently banned and where legal protections for the embryo are enshrined in the constitution, IVF is permitted, 
and it is usual to implant three embryos in the hope and expectation of achieving no more than a single live birth.

Even if we could accurately predict in advance which embryos would survive and which would not, the ethics would not change. Suppose that for some biological reason there was a condition that required that, for one embryo to implant, it was necessary to introduce a companion embryo that would not, and we could tell in advance which would be which. It is difficult to imagine how or why this fact would alter the ethics of the procedure; it would remain the case that one must die in order that the other would survive. If people in this condition wanted ART, would we judge it unethical to provide it to them but not to "normal" IVF candidates when the "costs" were the same in each case-namely, the loss of one embryo in pursuit of a healthy birth?

It might be objected that the parallel with sexual reproduction is like saying that, because we know that road traffic causes thousands of deaths per year, to drive a car is to accept that the sacrifice of thousands of lives in almost every country, for example, is a price worth paying for the institution of motor transport. This might seem a telling analogy showing that we do not willingly accept the inevitable consequences of what we do. There are, of course, many disanalogous features of the purported reductio ad absurdum comparison with road deaths. The vast majority of drivers will go all their lives without having an injury-causing incident, let alone a fatality, and the probability of any individual causing a death once exacerbating factors such as alcohol use and reckless fatigue are taken into account is vanishingly small by any standards and insignificant when compared with the high risk of production of embryos in unprotected sex between fertile partners. However, suppose an individual knew that, despite a long driving career without accidents, today is the day that either they will surely be involved in a fatal accident and cause someone's death or that the probability of this happening is very high indeed. Would it be conceivable that it might be permissible, let alone ethical, to drive today? And yet that is the situation with normal sexual intercourse, at least for those who regard the embryo as protected.

The natural is not connected to the moral. It is important to be clear about the form of this argument. I am not, of course, suggesting that because something happens in nature it must be morally permissible for humans to choose to do it. I am not suggesting that, because embryos are produced only to die in natural procreation, that the killing of embryos must be morally sound. I am saying, rather, that if something happens in nature and we find it acceptable in nature given all the circumstances of the case, then if the circumstances are relevantly similar it will for the same reasons be morally permissible to achieve the same result as a consequence of deliberate human choice. I am saying that we do as a matter of fact and of sound moral judgment accept the sacrifice of embryos in natural reproduction, because although we might rather not have to sacrifice embryos to achieve a live healthy birth, we judge it to be defensible to continue natural reproduction in the light of the balance between the moral costs and the benefits. And if we make this calculation in the case of normal sexual reproduction we should, for the same reasons, make a similar judgment in the case of the sacrifice of embryos in stem cell research.

To take a different but analogous case: if we say that God and/or nature "approves" of cloning by cell division because of the high rate of natural 
monozygotic twinning ${ }^{49}$ and that therefore the duplication of the human genome is not per se unethical we are not saying that cloning by cell division is ethically unproblematic because it occurs naturally. The point of the analogy is rather that, because the birth of natural identical twins is generally not considered regrettable, we are reminding ourselves that there is nothing here to regret. Indeed, it is the occasion for unmitigated joy or at least moral neutrality. We should, therefore, unless we can find a difference, feel the same about choosing deliberately to create twins by duplication of the human genome. ${ }^{50}$ If we then object to cloning by a different method, cell nuclear transfer objections must obviously be to features that arise uniquely in cell nuclear transfer and cannot simply be to such features as duplication of the human genome. Our acceptance of the natural does not, of course, apply to naturally occurring premature death; here we do think there is something to regret, even if it is natural and inevitable.

Instrumentalization revisited. Another possible concern involves a version of the instrumentalization objection that demands that embryos not be produced only to be used for the benefit of others but that, as in sexual reproduction, they should all have some chance of benefiting from a full normal lifespan. ${ }^{51}$ In normal sexual reproduction, embryos must be created only to die so that a sibling embryo can come to birth. But, arguably, it is in each embryo's interest that reproduction continues because it is the embryo's only chance to be the one that survives. Embryos (if they had rationality) would have a rational motive to participate (albeit passively) in sexual reproduction. By contrast, so it might be claimed, embryos produced specifically for research would not rationally choose to participate for they stand to gain nothing. All research embryos will die, and none have a chance of survival. If this argument is persuasive against the production of research embryos, it is easily answered by ensuring that the embryos produced for research have to some appropriate extent a real chance of survival. One would simply have to produce more embryos than are required for research, randomize allocation to research, and ensure that the remainder are implanted with a chance to become persons. To ensure that it would be in every embryo's interest to be "a research embryo," all research protocols permitting the production of research embryos would have to produce extra embryos for implantation. To take a figure at random but one that, as it happens, mirrors natural reproduction and gives a real chance of survival to all embryos, we could ensure that for every, say, 100 embryos needed for research another 10 would be produced for implantation. The 100 embryos would be randomized 90 for research, 10 for implantation, and all would have a chance of survival and an interest in the maintenance of a process that gave them this chance.

The third case concerns spare embryos that become available for research as a result of an ART program in which they have been produced and to which they are now superfluous because their "mother" has now declined for whatever reason to accept more embryos for implantation and has refused consent for their implantation into others. Here it might be suggested that these embryos are also like the research embryos just considered. However, this is not the case. These embryos have had their chance of implantation, but unfortunately for them, they have missed out. The fact that now they are irredeemably surplus to requirements for implantation does not show that they 
always were. These embryos have had their chance of life, their "motive" for participating in the program is as strong as in sexual reproduction or randomized research embryos.

Born to die. The force of the sexual reproduction analogy may seem vulnerable to the following claim. ${ }^{52}$ It can be said that, just as parents are responsible for the deaths of the embryos inevitably produced as a consequence of unprotected intercourse, so also and to the same extent are they responsible for the deaths of the children they actually produce when these children eventually die of old age. This is because in each case the parents have produced a life, which will end at a particular point and that point is in each case out of the parents' control. So, if parents are responsible for the deaths of the embryos lost as a result of unprotected intercourse, they are also responsible for the deaths of their children lost in old age. In neither case, however, have the parents been the proximate cause of death, but they have caused the life and death cycle. This objection, like the objection from the acceptability of motorized road transport, purports to constitute a reductio ad absurdum.

This is a puzzling objection. As I have argued, people accept the necessity of and the justification for producing surplus embryos because they wish to have a baby. Those who judge the embryo to have moral importance comparable to adults or children will have to justify their instrumentalization of the embryos that are sacrificed to this end.

On the other hand, those who think that dying of old age or being given a worthwhile life is a good will see nothing to justify. The parents are responsible for that life, to be sure, but they are morally justified in that responsibility, and in that the life for which they are responsible has been or is reasonably likely to be a worthwhile life, then, unless they have also arranged the death, their responsibilities have been exercised in a way that is both morally and socially appropriate.

The life of their child was in this case neither created nor ended to be a means to the interests of others. It is a good life, the creation of which requires no justification and the end of which was neither caused by the parents nor was its timing predictable by them. They therefore have no excuses to make. By contrast, the lives of the embryos that must die early are, if those lives are morally important at all, not lives the ending of which is a reasonable price to pay for the life lived.

The United States condemns human reproduction! Shocked by the idea of any activity that threatens the embryo, the U.S. government has adopted the revolutionary strategy of attempting to condemn human reproduction and, for good measure, has included all unprotected intercourse in the condemnation and to ban all federal support for such activities.

How have our cousins in the United States arrived at this daring and groundbreaking social policy? In the United States, current federal law prohibits the use of federal funds for "the creation of a human embryo" explicitly for research purposes or, more crucially, for "research in which a human embryo or embryos are destroyed, discarded or knowingly subjected to the risk of injury or death." 53 Such law is presumably animated by concern about the morally problematic nature of such actions and also by the idea that federal support in 
the form (among others) of "tax dollars" should not be given to activities that a significant number of people find offensive or objectionable. As I have noted, normal sexual reproduction inevitably involves a process in which a human embryo or embryos are destroyed or discarded. It is also incontrovertibly an activity in which a human embryo or embryos are "knowingly subjected to the risk of injury or death," at least for anyone who knows the facts of life. The perpetuation of this position seems likely, as President George W. Bush had made an election promise never to provide federal support for research that involves living human embryos. Those who can read his lips may have less confidence that this promise will be kept.

Consistency with attitudes to and moral beliefs about abortion and assisted reproduction. In most countries of the European Union and indeed in most countries of the world, abortion is permissible under some circumstances. Usually, permissibility is considered greater at very early stages of pregnancy, permissibility waning with embryonic and fetal development. The most commonly accepted ground for abortion (where it is acceptable) is to protect the life and the health of the mother. Sometimes the idea of protection of the life and health of the mother is very broadly and liberally interpreted, as it is in the United Kingdom; sometimes the requirement is very strict, demanding real and present danger to the life and health of the mother (Northern Ireland, for example). Given that the therapies initially posited for stem cell research-the treatment of Parkinson's disease and the development of tailor-made transplant organs-are all for serious diseases that threaten life and dramatically compromise health, it is difficult to see how those who think the sacrifice of early embryos for these purposes is or could be justified could find principled objections to the use of embryos in other lifesaving therapies. ${ }^{54}$

The same is, of course, true, as I have already noted of ART. All IVF involves the creation of spare embryos, and all IVF now practiced is built on research done on many thousands of embryos. Most countries and most religions accept IVF and its benefits and in doing so accept that spare embryos will be produced only to die. Even Germany, which has, as I noted, an Embryo Protection Act, accepts the practice of implanting up to three embryos in the hope and expectation that at least one will survive. The acceptance of the practice of IVF is necessarily an acceptance that embryos may be created and destroyed for a suitably important moral purpose.

The Principle of Waste Avoidance. As I stated previously, this widely shared principle states that it is right to benefit people if we can and wrong to harm them, and that, faced with the opportunity to use resources for a beneficial purpose when the alternative is that those resources are wasted, we have powerful moral reasons to avoid waste and do good instead.

That it is surely better to do something good than to do nothing good should be reemphasized. It is difficult to find arguments in support of the idea that it could be better (more ethical) to allow embryonic or fetal material to go to waste than to use it for some good purpose. It must, logically, be better to do something good than to do nothing good; it must be better to make good use of something than to allow it to be wasted. It must surely be more ethical to help people than to help no one. This principle-that, other things being equal, 
it is better to do some good than no good-implies that tissue and cells from aborted fetuses should be available for beneficial purposes in the same way that it is ethical to use organs and tissue from cadavers in transplantation.

It does not follow, though, that it is ethical to create embryos specifically for the purposes of deriving stem cells from them. However, as I discussed, there may be problems in objecting to creating embryos for this purpose from people who do not object to the sacrifice of embryos in pursuit of another supposedly beneficial objective-namely, the creation of a new human being. Only those who think that it is more important to create new humans than to save existing ones will be attracted to the idea that sexual reproduction is permissible whereas the creation of embryos for therapy is not.

\section{Notes}

1. And we were young. With apologies to A. E. Houseman, Parta quies.

2. Whereas other equally platitudinous but also totally incoherent principles, like the appeal to human dignity, so often occupy center stage.

3. Nor anyone who even believes that unprotected sexual intercourse is permissible.

4. Of course, there may be specific research projects that are unethical.

5. Thomson JA, Itskovitz-Elder J, Shapiro SS, Waknitz MA, Swiergiel VS, Jones JJ. Embryonic stem cell lines derived from human blastocysts. Science 1998;282(Nov 6):1145-47.

6. Pedersen R. Embryonic stem cells for medicine. Scientific American. 1999;April:69.

7. De Rijk MC, Launer LJ, Berger K, Breteler MMB, Dartigues J-F, Baldereschi M et al. Prevalence of Parkinson's disease in Europe. Neurology 2000;54(11;S5):21-3.

8. Schrag A, Ben-Shlomo Y, Quinn NP. Cross sectional prevalence survey of idiopathic Parkinson's disease and Parkinsonism in London. BMJ 2000;321(7252):21-2.

9. Parkinson's Disease Society. Who gets Parkinson's? Available at: http://www.parkinsons.org.uk/ docs $/$ viewdoc.asp? ID =105\&catid $=29$ \&nodeid $=224$.

10. Parkinson's Disease Foundation. Parkinson's disease: an overview. Available at: http:// www.pdf.org/aboutPD/.

11. Harris J. Intimations of immortality. Science 2000;288(5463):59. Harris J. Intimations of immortality: the ethics and justice of life extending therapies. In: Freeman M, ed. Current Legal Problems. Oxford: Oxford University Press; 2002.

12. And perhaps most religionists too, but that is a different kind of immortality.

13. Kirkwood T. Time of Our Lives. London: Weidenfeld and Nicolson; 1999; Kirkwood T. The End of Age. London: Profile Books; 2001.

14. See note 11 Harris 2000, Harris 2002.

15. For more on the ethics of genetic enhancement, see: Harris J. Clones, Genes, and Immortality. New York: Oxford University Press; 1998.

16. This section was researched and substantially drafted by my colleague Louise Irving. I am grateful to her here as elsewhere for help and advice.

17. Stem Cell Research: Medical Progress with Responsibility Department of Health June 2000. Government Response to the Recommendations made in the Chief Medical Officer's Expert Group Report "Stem Cell Research: Medical Progress with Responsibility." Presented to Parliament by the Secretary of State for Health by Command of Her Majesty, August 2000. The Stationary Office CM4833.

18. And also insupportable claim unless the immorality consists solely in the fact that as yet cloning by cell nuclear transfer is untested and probably unsafe in humans. For a detailed attempt to demonstrate that there are no good moral arguments against cloning, see: Harris J. Goodbye Dolly: the ethics of human cloning. Journal of Medical Ethics 1997;23(6):353-60; Harris J. Cloning and human dignity. Cambridge Quarterly of Healthcare Ethics 1998;7(2):163-8; Harris J. Genes, clones, and human rights. In: Burley JC, ed. The Genetic Revolution and Human Rights: The Amnesty Lectures 1998. New York: Oxford University Press; 1999:61-95.

19. See note 18, Harris 1999.

20. This is the case in France, Germany, Ireland, Lithuania, and Switzerland. 


\section{John Harris}

21. This has been legal in the United Kingdom since the 1990 Human Fertilisation and Embryology Authority Act came into force.

22. The Eighth Amendment of the Constitution Act 1983 reads, "Acknowledged the right to life of the unborn, with due regard to the equal right to life of the mother," 7 October 1983, in Constitution of Ireland. Available at: http://www.taoiseach.gov.ie/viewitem.asp?id=297\&lang=ENG.

23. Frydrych M. Abortion not considered in enlargement rules. Available at http://www. euobserver.com/index.phtml?aid-4646.

24. The Opinion of the European Group on Ethics in Science and New Technologies to the European Commission, No. 15. Ethical Aspects of Stem Cell Research and Use 2000 Nov 14:11.

25. Spanish regulation is through The Assisted Reproduction Techniques Act of 1988, taken from: European Commission Research Directorate-General. The Spanish Survey on Human Embryonic Stem Cells. In: Matthiessen L, ed. Survey on Opinions from National Ethics Committees or Similar Bodies Public Debate and National Legislation in Relation to Human Embryonic Stem Cell Research and Use. Brussels, Belgium: European Commission Research Directorate-General; 2001.

26. See: Lanza RP, Caplan AL, Silver LM, Cibelli JB, West MD, Green RM. The ethical validity of using nuclear transfer in human transplantation. JAMA 2000;284(24):3175.

27. See note 24, European Commission 2000:12.

28. The Convention of the Protection of Human Rights and Dignity of the Human Being with Regard to the Application of Biology and Medicine: Convention on Human Rights and Biomedicine states: "(1) where the law allows research on embryos in vitro, it shall ensure adequate protection of the embryo; and (2) the creation of embryos for research purposes is prohibited."

29. The Charter of Fundamental Rights of the European Union. Available at: http://ue.eu.int/df/ docs/en/CharteEN.pdf.

30. The European Group on Ethics in Science and New Technologies to the European Commission. Available at: http://europa.eu.int/comm/european_group_ethics/index_en.htm.

31. German bishop capitulates on abortion. BBC News [online] 2002 Mar 8. Available at: http:// news.bbc.co.uk/2/hi/europe/1862662.stm.

32. Marantha Christian Journal [online]. Available at: http://www.mcjonline.com.

33. The European Commission Research Directorate-General. Statement of the Central Ethics Committee on Stem Cell Research 23.11.01 (nonofficial translation) annexe. In: Matthiessen L, ed. Survey on Opinions from National Ethics Committees or Similar Bodies Public Debate and National Legislation in Relation to Human Embryonic Stem Cell Research and Use. Brussels, Belgium: European Commission Research Directorate-General; 2001.

34. Schiermeier Q. German Parliament backs stem-cell research. Nature 7 Feb 2002;415:566. See also: Heinemann T, Honnefelder L. Principles of ethical decision making regarding embryonic stem cell research. Bioethics 2002;16:530-43.

35. European Commission Research Directorate-General. Opinion on the preliminary draft revision of the laws on bioethics of the Comité Consultatif National d'Ethique pour les Sciences (CCNE). In: Matthiessen L, ed. Survey on Opinions from National Ethics Committees or Similar Bodies Public Debate and National Legislation in Relation to Human Embryonic Stem Cell Research and Use. Brussels, Belgium: European Commission Research Directorate-General; 2001.

36. See note 36, European Commission Research Directorate-General 2001.

37. See note 36, European Commission Research Directorate-General 2001.

38. de Beaufort I, English V. Between pragmatism and principles? on the morality of using the results of research that a country considers immoral. In: Gunning J, ed. Assisted Conception: Research, Ethics, and Law. Aldershot, UK: Dartmouth; 2000. See also: Green RM. Benefiting from evil: an incipient moral problem in human stem cell research and therapy. Bioethics 2002;16:544-56.

39. European Commission Research Directorate-General. Italian National Bioethics document. In: Matthiessen L, eds. Survey on Opinions from National Ethics Committees or Similar Bodies Public Debate and National Legislation in Relation to Human Embryonic Stem Cell Research and Use. Brussels, Belgium: European Commission Research Directorate-General; 2001.

40. See note 40, European Commission Research Directorate-General 2001.

41. See: Harris J. Wonderwoman and Superman: The Ethics of Human Biotechnology. New York: Oxford University Press; 1992; see also note 15, Harris 1998.

42. See note 19, Harris 1997, Harris 1998, Harris 1999.

43. International Herald Tribune 2002 Jun 22-23:1. In a paper presented at FENS Forum Workshop, Paris, 13 Jul 2002, Austin Smith emphasized the importance of pursuing research on all sources of stem cells simultaneously. 
44. McKay R. Stem cells-hype and hope. Nature 2000;406:361-4.

45. Pedersen R. Embryonic steps towards stem cell medicine. Paper presented at the EUROSTEM conference Regulation and Legislation under Conditions of Scientific Uncertainty. 2002 Mar 6-9; Bilbao, Spain. The conference was supported by a Project Grant from The European Commission Directorate-General for Research, "Quality of Life."

46. Robert Winston gave the figure of five embryos for every live birth some years ago in a personal communication. Anecdotal evidence to me from a number of sources confirms this high figure, but the literature is rather more conservative, making more probable a figure of three embryos lost for every live birth. See: Boklage CE. Survival probability of human conceptions from fertilization to term. International Journal of Fertility 1990;35(2)75-94. See also: Leridon H. Human Fertility: The Basic Components. Chicago: University of Chicago Press; 1977. Again, in a recent personal communication, Henri Leridon confirmed that a figure of three lost embryos for every live birth is a reasonable conservative figure.

47. For a conclusive refutation of that doctrine, see: Harris J. Violence and Responsibility. London: Routledge and Kegan Paul; 1980. For a more recent discussion of these broad issues, see: Kamm FH. The doctrine of triple effect and why a rational agent need not intend the means to his end. Proceedings of the Aristotelian Society (Supplementary volume) 2000;74:21-39; and Harris J. The moral difference between throwing a trolley at a person and a throwing a person at a trolley: a reply to Francis Kamm. Proceedings of the Aristotelian Society (Supplementary volume) 2000;S74:40-57.

48. Some hedonistic utilitarians, for example.

49. Human monozygotic twinning occurs in roughly one per 270 births (three per 1,000). I take this figure of the rate of natural twinning from: Moore KL, Persaud TVN. The Developing Human, 5th ed. Philadelphia: W. B. Saunders; 1993.

50. Or indeed cloning by cell nuclear substitution, but that is another story. For the full story, see note 18, Harris 1997.

51. The possible objection was put to me by Julian Savulescu - the response to it with all its defects is mine.

52. A point made to me by Louis G Aldrich at the Third International Conference of Bioethics, National Central University, Shungli, Taiwan. 2002 Jun 24-29.

53. U.S. Public Law 105-277, sect. 511, 1998 Oct 21, slip copy. H.R. 4328.

54. See Harris J. Should we experiment on embryos? In: Lee R, Morgan D, eds. Birthrights: Law and Ethics at the Beginnings of Life. London: Routledge; 1988:85-95. 